\title{
MEDIA ACCESS TO REFUGEE PROCEEDINGS IN CANADA
}

\section{MARLYS EDWARDH and DANIEL BRODSKY*}

The authors explore the mechanism adopted by Parliament to afford a refugee claimant and his or her family the protection of a qualified shield. They begin the investigation by noting that open proceedings are the general rule in Canada, and in camera hearings are the exception. The statutory provisions which allow the reversal of the open hearing rule are analyzed with particular attention to the question of which burdens must be satisfied by the person seeking a hearing that is less than open. The balancing of competing rights under the Charter of Rights is reviewed with respect to the right of the public to have access to the courts and the rights of the refugee claimant to his or her privacy, security of the person and a fair trial. The various factors taken into consideration by a court considering the exclusion of members of the public from $a_{\text {, refugee }}$ hearing are listed, including those found in the Immigration Act. The authors conclude that the restrictions on access to refugee hearings are reasonable and can be demonstrably justified in $a$ free and democratic society.
Les auteurs examinent le mécanisme qu'adopte le Parlement pour donner une protection relative à un demandeur réfugié et à sa famille. Ils commencent leur enquête en notant que les délibérations publiques sont la règle générale au Canada et que les débats à huit clos sont l'exception. Ils passent en revue les dispositions prévues par la loi et s'attachent particulièrement aux obligations auxquelles doit satisfaire la personne qui recherche une audience qui ne soit pas publique. Ils étudient les droits conflictuels qui existent sous la Charte, lesquels garantissent d'une part le droit d'accès du public aux tribunaux et d'autre part les droits du demandeur réfugié — droit a la protection de sa vie privée, a la sécurité de sa personne et à un procès équitable. Ils énumèrent divers facteurs qu' un tribunal prend en considération avant d'exclure les membres du public d'une audience, dont ceux prévus par la Loi sur l'immigration. Les auteurs concluent que les limites d'accès aux audiences relatives aux réfugiés sont raisonnables et qu'on peut en justifier le bien-fondé dans une société libre et démocratique.

\section{TABLE OF CONTENTS}

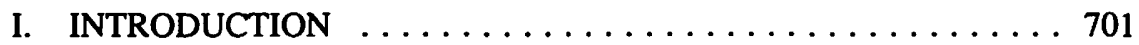

II. THE REFUGEE CLAIM IN CANADA $\ldots \ldots \ldots \ldots \ldots \ldots \ldots 702$

III. THE LEGISLATIVE FRAMEWORK $\ldots \ldots \ldots \ldots \ldots \ldots \ldots 703$

IV. BURDEN OF PROOF . . . . . . . . . . . . . . . . . 704

V. WOULD NOT IMPEDE THE PROCEEDINGS $\ldots \ldots \ldots \ldots \ldots 706$

VI. ADVERSE EFFECT ON CLAIMANT'S FAMILY $\ldots \ldots \ldots \ldots 710$

VII. CONCLUSION $\ldots \ldots \ldots \ldots \ldots \ldots \ldots \ldots \ldots \ldots \ldots \ldots$

\section{INTRODUCTION}

It is a basic principle of natural justice that a judicial or quasi-judicial hearing be open to the public, save certain exceptions. In 1913, Lord Halsbury set out the principle that "every court of justice is open to every subject of the King". ${ }^{1}$ In the same case, Lord Atkinson ruled that: ${ }^{2}$

The hearing of a case in public may be, and often is, no doubt, painful, humiliating, or deterrent both to parties and witnesses, and in many cases, especially those of a criminal nature, the details may be so

Ruby \& Edwardh, Barristers \& Solicitors, Toronto, Ontario

I. Scott v. Scott, [1913] A.C. 417 at 440 (H.L.).

2. Ibid. at 463 . 
indecent as to tend to injure public morals, but all this is tolerated and endured, because it is felt that in a public trial is to [be] found, on the whole, the best security for the pure, impartial, and efficient administration of justice, the best means for winning for it public confidence and respect.

In the Canadian context, Dickson J., in MacIntyre v. A.G.N.S., formulated the following limit on the open court rule: "curtailment of public accessibility can only be justified where there is present the need to protect social values of superordinate importance." ${ }^{3}$ Although this broad principle was begotten in reference to trial courts, it has been expanded to include statutory tribunals exercising judicial or quasi-judicial functions. The Federal Court of Canada (Trial Division), in Southam Inc. v. M.E.I., affirmed this in the administrative law context in ruling that: ${ }^{4}$

\footnotetext{
...statutory tribunals exercising judicial or quasi-judicial functions involving adversarial-type processes which result in decisions affecting rights truly constitute part of the "administration of justice". The legitimacy of such tribunals' authority requires that confidence in their integrity and understanding of their operations be maintained, and this can be effected only if their proceedings are open to the public.
}

It is important to note that the common law which Canada adopted from England had certain class exemptions to the concept of openness. Most notable is the refugee claim, which has always been held in camera. The current practice with respect to persons seeking asylum in England is to have an administrative officer of the Home Office (with no decision-making authority) interview the claimant, who is entitled to be represented by counsel. A report is prepared for the Refugee and Special Case Unit of the Immigration and National Department of the Home Office, who decides whether to accept or reject the claim with formal responsibility lying in the Secretary of State.

\section{THE REFUGEE CLAIM IN CANADA}

The Immigration Act ${ }^{5}$ contemplates a two-step process in determining the validity of claims for refugee status, which are made by the Immigration and Refugee Board. ${ }^{6}$ Step one is an initial hearing held before a panel of two. The panel members consist of an adjudicator who sits in consultation with a member of the Convention Refugee Determination Division of the Immigration and Refugee Board pursuant to section 48 of the Immigration Act. At this hearing a claimant has the burden of proving that he or she is eligible to have the claim for refugee status determined and that there is a credible basis for the claim. ${ }^{7}$ If either of the two panel members is persuaded that the claimant is both eligible as defined by the Act and has demonstrated a credible basis for the claim being made then the second step, the claim for refugee status, will be heard by the Refugee Division of the Board. ${ }^{8}$ A "Convention Refugee" is defined as a person who:" 
2(1)(a) by reason of a well founded fear of persecution for reasons of race, religion, nationality, membership in a particular social group or political opinion

(i) is outside the country of his nationality and is unable or, by reason of that fear, is unwilling to avail himself of the protection of that country, or

(ii) not having a country of nationality, is outside the country of his former habitual residence and is unable or, by reason of that fear, is unwilling to return to that country...

\section{THE LEGISLATIVE FRAMEWORK}

Subsections $29(2)$ and $29(3)$ apply to the first step, the credible basis hearing, and provide that: ${ }^{10}$

29 (2) At the request or with the permission of the person with respect to whom an inquiry is to be held, an adjudicator shall allow any person to attend an inquiry if such attendance is not likely to impede the inquiry.

29 (3) Except as provided in subsection (2), an inquiry by an adjudicator shall be held in camera unless it is established to the satisfaction of the adjudicator, on application by a member of the public that the conduct of the inquiry in public would not impede the inquiry and that the person with respect to whom the inquiry is to be held or any member of that person's family would not be adversely affected if the inquiry were to be conducted in public.

Subsections 69(2) and 69(3) apply to the full hearing by the Refugee Division of the Immigration and Refugee Board, the second step, and provides that: ${ }^{11}$

69 (2) Subject to subsection (3), proceedings before the Refugee Division shall be conducted in camera unless it is established to the satisfaction of the Division, on application by a member of the public, that the conduct of the proceedings in public would not impede the proceedings and that the person who is the subject of the proceedings or any member of that person's family would not be adversely affected if the proceedings were conducted in public.

69 (3) The Refugee Division shall allow any representative or agent of the United Nations High Commissioner for Refugees to attend any proceedings before it as an observer and, at the request or with the consent of the person who is the subject of the proceedings, shall allow any other person to attend the proceedings as an observer if, in the opinion of the Division, the attendance of that other person is not likely to impede the proceedings.

These sections of the Immigration Act reverse the general principle that hearings ought to be open to the public. Subsections 29(3) and 69(2) prescribe that refugee hearings are to be in camera, absent the request of, or with the permission, of the person in respect of whom the hearing is being held. This reversal of the rule is subject to a few exceptions. An application for access may be brought by any member of the public pursuant to $\mathbf{s}$. 29(3) (during a credible basis hearing) or s. 69(2) (during a full refugee hearing). In

10. Ibid. ss. $29(2)$ and $29(3)$.

11. Ibid. ss. 69(2) and 69(3). 
order to grant the application, evidence must establish to the satisfaction the tribunal that: ${ }^{12}$

(1) the conduct of the proceedings in public would not impede the inquiry; and

(2) that the person, with respect to whom the inquiry or hearing is to be held, or any member of that person's family, would not be adversely affected if the inquiry were held in public. This reversal is intended to balance the public's valid interest in the openness of legal proceedings generally against the right of a refugee claimant to present his or her claim as effectively as possible. The provisions are sensitive to the fact that the claimant is in a foreign land, may not speak the language, and recognizes the very real danger to the claimant or to the claimant's family if the facts and details of the claim become public knowledge and, if the claim is refused, come to the attention of the authorities in the country from which the claimant fled.

\section{BURDEN OF PROOF}

In the recent case of Toronto Star v. Kenney, the matter of who bears the burden of raising the issue of access to the proceedings and satisfying the tribunal that both branches of the test are met was considered by the Federal Court (Trial Division). ${ }^{13}$ This case arose in the following context: on August 21, 1989 Mahmoud Mohammad Issa Mohammad's credible basis hearing was convened to determine whether he had a credible basis for claim to be a convention refugee. At the hearing, Mohammad consented, pursuant to s. 29(2) of the Act, to the-presence of certain named members of the public, but not to the presence of media representatives. Subsequently, applications to have the hearing conducted in public were made by certain members of the public pursuant to $\mathrm{s}$. 29(3) of the Act.

Counsel for Mohammad submitted that an applicant must bear the burden of raising the issue of access, and must satisfy the tribunal that the conduct of the inquiry in public would not impede it and that neither Mohammad, nor any member of his family, would be adversely affected if the inquiry were to be conducted in public. Further, counsel was prepared to call evidence if it could be called in camera, otherwise it was argued that the prejudicial evidence would effectively be disseminated at the hearing of the access application.

Martin J., in Toronto Star, adopted the following obiter comment of Mahoney J. in Pacific Press v. M.E.I.: ${ }^{14}$

It seems to me that the assertion of a right to access to a judicial or quasi-judicial proceeding founded on s. 2(b) of the Charter must, of itself, inferentially satisfy that subject burden and shift the onus to the person seeking to exclude the press.

12. Southam Inc. v. M.E.I., unreported, Jerome J., April 28, 1989 (F.C.T.D.) at 4.

13. Toronto Star v. Joseph Kenney, unreported, Martin, J., February 13, 1990 (F.C.T.D.) at 6.

14. Pacific Press v. M.E.I., unreported, Mahoney J., January 26, 1990 (F.C.A.D.) at 3-4; ibid. at 17. 
Martin J. ruled that the applicant indeed bears the burden of raising the issue of access. However, the burden is on the refugee claimant to establish the existence of an environment which will diminish his ability to fully disclose the facts which support his refugee claim. Martin J. stated that: ${ }^{15}$

Counsel for the applicants submits, as already indicated, that although s. 29(3) is drafted in form to provide for the discretion principle contained in the Southam No. 1 decision, in substance and in fact there is no discretion if the Court applied a literal interpretation to it. In order to save s. 29(3) from constitutional death he submits it must be interpreted in such a way as to have due regard for the freedom of the press in its right, along with the right of the general public, to have access to judicial proceedings.

His submission is, and I agree with him, that to apply the literal meaning of s. 29(3) burden of proof upon the applicants in this case, and in general, is to apply a burden which is impossible to discharge. How can, for example, the applications prove to the satisfaction of the adjudicator that no member of Mohammad's family would be adversely affected if the inquiry were to be conducted in public when the applicants may not, and in most cases will not, have any idea who or where are the members of the refugee claimant's family... . Likewise it is impossible for the applicants in this case or any other case to prove that the conduct of the inquiry in public would impede it. To some extent the answer to that question will depend upon the evidence which the refugee claims to intend to lead.

And further that: ${ }^{16}$

In my view, if the burden of proof or onus of proof apparently placed upon the member of the public by s. 29(3) is, as a practical matter, one which is impossible to discharge and, if the exercise of the adjudicator's discretion in favour of conducting the hearing in public is dependent upon the member of the public meeting that burden or discharging that onus, then in fact and in substance there is no discretion and s. 29(3) would have to be declared unconstitutional on the basis of Southam (No. I).

The meaning of the word "satisfied" was examined in Blyth v. Blyth (No. 2), where Lord Morris of Borth-y Gest ruled that: ${ }^{17}$

The word satisfied is a clear and simple one and one that is well understood ... it needs no addition. From it there should be no subtraction. The courts must not strengthen it: nor must they weaken it. Nor would I think it desirable that any kind of gloss should be put on it. When Parliament has ordained that a court must be satisfied only Parliament can prescribe a lesser requirement. No one, whether he be judge or juror, would in fact be "satisfied" if he was in a state of reasonable doubt (emphasis added).

Therefore, if after hearing the evidence called by a Claimant the tribunal is left with a doubt on either branch of the test, then the public's access must be restricted.

\section{Supra, note 13 at 15 .}

16. Ibid. at 16.

17. Supra, note 5, ss. 29(3) and 69(2); Blyth v. Blyth No. 2, [1966] 1 All E.R. 524 at 530 (H.L.); see also R. v. Moulton (1979), 13 C.R. (3d) 143 at 158-159 (Alta. C.A.); see also Clark v. The Queen (1921), 61 S.C.R. 608. 
In considering the method of presenting the necessary supporting evidence under conditions that prevent dissemination of evidence during an application, Martin J. considered the comments of Mahoney J. in Pacific Press v. M.E.I. where he stated that: ${ }^{18}$

The problem faced by the Adjudicator arose directly out of his refusal to conduct in camera the proceedings on the Applicants' request that the inquiry be open. As a result of that, McVey refused to lead evidence. On the assumption that in camera proceedings in an inquiry under the Immigration Act may be justified notwithstanding s. 2(b) of the Charter, it seems obvious that the person seeking to exclude the press ought to be afforded the opportunity to present the necessary supporting evidence under conditions that will prevent its disclosure and publication. Experienced counsel will be able to suggest a variety of acceptable measures to maintain confidentiality while allowing the evidence to be tested by adverse interests.

In Toronto Star v. Kenney, the novel method to maintain confidentiality was for the applicants' counsel to give an undertaking, on consent of his client, to confidentiality which would be between themselves and their clients, the press. ${ }^{19}$ Though appropriate in the Toronto Star case, this type of undertaking might be totally unenforceable in the context of an unrepresented member of the public bringing an application in person.

\section{WOULD NOT IMPEDE THE PROCEEDINGS}

There is no indication that a tribunal is limited to the consideration of only physical impediments or delay when applying the first branch of the test set out in subsections 29(3) and 69(2). The word "impede" has received little or no judicial consideration, but must of necessity include factors that would cause the functioning of a tribunal to lose its efficacy. In a parallel context, the Supreme Court of Canada, in A.G.N.S. v. MacIntyre, held that allowing the public access to a search wartant prior to its execution would undermine its efficacy. ${ }^{20}$ Dickson J. held that: ${ }^{21}$

The point taken here is that the effective administration of justice would be frustrated if individuals were permitted to be present when the warrants were issued. Therefore, the proceeding must be conducted in camera, as an exception to the open Court principle. I agree. The effective administration of justice does justify the exclusion of the public from the proceedings attending the actual issuance of the warrant. The Attorneys-General have established, at least to my satisfaction, that if the application for the warrant were made in open Court the search for the instrumentalities of crime would, at best, be severely hampered and, at worst, rendered entirely fruitless.... I agree with counsel for the Attorney-General of Ontario that the presence in an open court-room of members of the public, media personnel, and potentially, contacts of suspected accused in respect of whom the search is to be made, would render the mechanism of a search warrant utterly useless.

Supra, note 14 at 4.

Supra, note 13 at 18.

MacIntyre v. A.G.N.S., supra, note 3; see also A.G.B.C. v. Pacific Press Ltd. (1988), 28 B.C.L.R. 127

(B.C.S.C.).

Ibid. at 187-188. 
Section 2(b) of the Charter ${ }^{22}$ provides that:

2. Everyone has the following fundamental freedoms:

(b) Freedom of thought, belief, opinion and expression, including freedom of the press and other media of communication.

The guarantee of freedom of the press includes a right of access to judicial or quasi-judicial hearings. MacKinnon J., ruling for the Ontario Court of Appeal in $R e$ Southam and The Queen (No.1), stated that: ${ }^{23}$

It is true, as argued, that free access to the courts is not specifically enumerated under the heading of fundamental freedoms but, in my view, such access, having regard to its historic origin and necessary purpose already recited at length, is an integral and implicit part of the guarantee given to everyone of freedom of opinion and expression which, in terms, includes freedom of the press. However the rule may have had its origin, as Mr. Justice Dickson pointed out, the "openness" rule fosters the necessary public confidence in the integrity of the court system and an understanding of the administration of justice.

The Supreme Court of Canada also adopted this view in Canadian Newspapers Co. $v$. A.G. of Canada, where Lamer J. ruled that: ${ }^{24}$

Freedom of the press is indeed an important and essential attribute of a free and democratic society, and measures which prohibit the media from publishing information deemed of interest obviously restrict that freedom.

Accordingly, sections 29 and 69 of the Immigration Act prima facie infringe the freedom of the press. However, the need to protect social values of superordinate importance constitutes an internal qualifier on the broad scope of the Charter's protection. That is, that the right to freedom of the press is not absolute, and must be balanced against competing rights where they exist. For example, in the context of whether sections 29 and 69 of the Immigration Act infringe the freedom of the press, the scope of the s. 2(b) Charter right is qualified by the competing rights found in $\mathrm{s} .7$ of the Charter.

The superordinate value to which public access to refugee hearings must yield is the right to a fair hearing by an impartial tribunal. This right is integral to the rules of natural justice, and is now a constitutionally guaranteed right under Section 7 of the Canadian Charter of Rights and Freedoms. Section 7 of the Charter is engaged when an individual claims to be a Convention refugee. There is a violation of $s .7$ if the claimant is deprived of his right to a fair hearing and, consequently, the security of his person, in a manner that is not in accordance with the principles of fundamental justice. The concept of fundamental justice includes the principles of procedural faimess, which require that the claimant be afforded an adequate opportunity to state his case.

23. Re Southam Inc. and The Queen (No. I) (1983), 41 O.R. (2d) 113 (C.A.); see also, Maclntyre v. A.G.N.S., supra, note 3.

24. [1988] 2 S.C.R. 122. 
If the presence of the public could deprive the refugee claimant of an adequate opportunity to state his case, then a conflict has arisen between the right of public access to quasi-judicial proceedings which is protected by section 2(b) of the Charter and a claimant's section 7 rights. In these circumstances the "individual's rights to a fair trial before an independent and impartial tribunal must prevail." ${ }^{25}$ Smith J., in $R$. v. Begley stated that: ${ }^{26}$

Even before the Charter, the right to a fair trial under the British system of justice was very vigilantly and jealously guarded by the courts. Fear of prejudice was always in the forefront of their concerns. And when the two interests, namely the freedom of the press and the right of an accused person to have a fair and unprejudiced trial, competed one with the other, the second was invariably held to be paramount. See Steiner v. Toronto Star Ltd. et al., [1956] O.R. 14, 1 D.L.R. (2d) 297, 114 C.C.C. 117, as one in a long line of Canadian and English cases... .

It could not have been in the contemplation of the new Fathers of Confederation that the rights of an accused person should be whittled down in the name of a general concept of the freedom of expression or freedom of the press. A weighing process must always take place in each individual case and the right to a fair trial being paramount, an appellate court or a court of competent jurisdiction will always be loath to interfere with the exercise of discretion.

We are here concerned with the operations of the cour which constitute one of our basic democratic institutions. One would think that where such institutions are in operation, freedom of the press should always prevail. It seems to me to the contrary; that to hold as virtually inviolate as I do and as the courts always have done, the right to a fair and impartial trial, has the effect of strengthening, not weakening. our judicial institution. (Emphasis added)

Accordingly, access to the public, in whole or in part, has been limited by many other courts or tribunals following this principle in an effort to guarantee the right to a fair trial. Considerations have included, inter alia, situations where:

1. a risk of harm to the physical safety of a witness was present (for example, the public may be denied access to an information backing a search warrant if the disclosure would risk identifying an informant), ${ }^{27}$

2. protection of a minor or innocent third party from unnecessary embarrassment or personal injury (that is, where the dissemination of personal information regarding persons not party to the proceedings can be avoided which would (H.C.J.). 
otherwise make it difficult to carry on family life and education within the community); ${ }^{28}$

3. the ability to properly marshal all relevant evidence placed before a trier of fact would be lost and therefore the ends of justice subverted (for example, where the evidence to be given came from a blackmailed witness); ${ }^{29}$

4. the information disclosed would be used for improper purposes.

In each of the circumstances above, courts have explored many creative alternatives with the objective of ensuring that the open court rule is limited to the least restrictive alternative, while reserving an effective forum in which a case may be presented. However, the Immigration Act and Regulations do not provide any discovery procedure or voir dire to allow the parties to disclose their evidence in private, and a tribunal does not have the power to ban the publication of all or part of a case once an observer has seen the evidence. Given the statutory framework of the Immigration Act, the concepts of access and bans of publication are merged. What the Act does provide is a procedure expressly designed to provide refugee claimants with sufficient protection while allowing the public access when their presence would not impede an inquiry. Sections 29 and 69 of the Act are a half-way house designed to meet constitutional requirements, and are particularly suited to the hearing process of refugee claims. More particularly, the legislation addresses the following potential impediments to the conduct of a claimant's open hearing:

1. some evidence to be tendered in support of a refugee claim, though essential to forward the claim, could not be submitted without endangering the lives and safety of innocent third parties;

2. evidence tendered may be the subject of widespread publication in both national and international media;

3. even if evidence is not published, it may be disseminated to foreign authorities and could put the claimant's life and safety in jeopardy if he or she was unsuccessful in putting forward a refugee claim and was returned to the "care" of this foreign authority;

4. if public access were to be granted over the express objection of the claimant and harm resulted, Canadian courts would be powerless to repair the damage. 


\section{ADVERSE EFFECT ON CLAIMANT'S FAMILY}

The second branch of the test in subsections 29(3) and 69(2) is sensitive to the fact that the dissemination of information can lead to reprisals by national authorities in the country of origin against a claimant or his or her family members. Though the definition of "family" does not extend to friends or associates, it is to be given a broad interpretation. Section 2(3.1) of the Immigration Regulations provides that: ${ }^{30}$

2(3.1) For the purpose of subsection 29(3) and 69(2) of the Act, as amended by S.C. 1988, c. 35, s. 18 , "family", with respect to the person who is the subject of the inquiry or proceedings, includes any relative of that person.

Certainly, the protection of innocent family members is a social value of superordinate importance. This branch of the test in subsections 29(3) and 69(2) places an additional duty upon the tribunal to consider whether the applicant's family would be adversely affected if the hearing were to be conducted in public, even if the tribunal were satisfied that the conduct of the proceedings in public would not be impeded. There is no authority or rationale which limits the concept of adversity simply to physical harm or safety. Rather, the tribunal ought to consider "adverse" in the broadest sense as including psychological and physical harm.

\section{CONCLUSION}

Even if one did not accept the internal qualifier approach to access, the infringement of freedom of the press in the context of a refugee claim and in the manner set out in the Immigration Act is a reasonable limit demonstrably justifiable in a free and democratic society under section 1 of the Charter. ${ }^{31}$ Section $3(\mathrm{~g})$ of the Immigration Act states that one of the legislative objectives of the Act is to fulfil Canada's international legal obligations with respect to refugees, and to uphold its humanitarian tradition with respect to the displaced and the persecuted. ${ }^{32}$ At a minimum, sections 29 and 69 of the Act seek:

1. to foster an environment in which a refugee claimant who fears persecution may freely divulge all facts in support of his claim;

2. to protect the refugee claimant in the event that his claim is rejected and he returns to the country from which he fled; and

3. to protect the family of the refugee claimant remaining in the country fled.

These objectives are sufficiently important to warrant limiting the freedom of the press. The restriction is not absolute, and the degree of the infringement varies proportionally to the importance of the Charter-protected superordinate interest. This limit is obviously 
rationally connected to the legislative objective sought, and impairs the freedom of the press as little as possible. ${ }^{33}$

If freedom of the press collides with the right of a refugee claimant to have a fair hearing, then this freedom must yield to the legal right of the claimant. This abrogation of freedom of the press in this context and in this forum is demonstrably justifiable in a free and democratic society. 